\title{
INFLUENCE OF DEVELOPMENT OF NATIONAL INNOVATION SYSTEMS ON THE ECONOMIC EFFICIENCY
}

\author{
Pavlo Ilchuk ${ }^{1}$ \\ Lviv Polytechnic National University, Ukraine \\ Iryna Mushenyk ${ }^{2}$ \\ State Agrarian and Engineering University in Podilya, Ukraine
}

\begin{abstract}
Development of modern economic system is taking place based on the concept of "knowledge economy". And thus the main method to stimulate economic development is to introduce innovations. Within the functioning of national innovation systems, there is the integration of science, education, capital, and production that, on the one hand, allows creating innovations and, on the other, stimulates the development of the economy precisely due to the formation of the synergetic effect of cooperation of many participants of innovative process. The subject of research is the interrelation of innovative activity with economic efficiency and economic growth at the macrolevel. Therefore, the purpose of the research is to evaluate influence of development of national innovation systems on the economic efficiency, and a number of tasks are carried out in order to achieve it: development of integrated indicators to evaluate operating efficiency of national innovation systems, identification of relationship between the level of development of national innovation systems and the level of economic development of countries, evaluation of development of individual national innovation systems, and determination of influence of the level of national innovation systems' development on the economic growth of countries. The methodology of research of influence of development level of national innovation systems on the economic growth of countries is based on building integral indices, which are calculated by using the method of geometric average of partial indices and construction of regression models, which allow evaluating the influence of development of national innovation systems on the economic efficiency. In the paper, the author's method of forming integral indicator to evaluate the level of development of national innovation systems is developed and a method of evaluating their influence on the economy is proposed. Testing of the methodology of evaluation of national innovation systems' development is carried out based on data of national innovation systems of six countries: Ukraine, Great Britain, Latvia, Germany, Poland, and France. The work proves the existence of a close positive interrelation between the index of national innovation systems' development and the index of GDP per capita, which is peculiar for all countries under study. Also, there are built regression models according to data of calculation of the index of national innovation systems' development and its elements with a quite high reliability, which allows using them in order to forecast GDP per capita under conditions of national innovation systems' development. Moreover, the paper identifies individual features of the influence of separate directions of the functioning of innovation systems on the level of economic development of the countries under study, which provides an opportunity to conduct strategic management for separate directions of the functioning of national innovation systems.
\end{abstract}

Key words: innovations, innovation system, development, economy, influence, integral indicator.

JEL Classification: 011, 031, 047

\section{Introduction}

Currently, development and increase in the efficiency of national economy acquire a special relevance. One of the ways to stimulate the development of the economy is to introduce innovations.
Foundations of the modern concept of innovative development of the economy in the early 90s of the XX century are developed by B.-A.Lundvall, C. Freeman, and R. Nelson. According to the main provisions of such a concept, efficiency of development of an innovation-

Corresponding author:

${ }^{1}$ Department of Management Technology, Lviv Polytechnic National University.

E-mail: pavlo.g.ilchuk@lpnu.ua

${ }^{2}$ Department of Information Technology, State Agrarian and Engineering University in Podilya/

E-mail:mushenik77@ukr.net 
based economy depends both on the efficiency of activities of separate subjects of innovative process and the efficiency of cooperation of all subjects of national innovation system during the creation and diffusion of innovations (Fedirko, 2007). Further research of the conceptual foundations for the formation of national innovation systems was carried out also by N. Sharif (2006), J. Fagerberg, D. Mowery (2005) and R. Nelson (2000), and other scholars.

Within the functioning of national innovation systems, there is the integration of science, education, capital, and production that, on the one hand, allows creating innovations and, on the other, stimulates the development of the economy precisely due to the formation of the synergetic effect of cooperation of many participants of innovative process. Thus, it is the level of development and efficiency of national innovation systems that determine the level of innovative capacity of the national economy, as well as the general level of economic competitiveness under conditions of global competition.

The purpose of the research is to evaluate the influence of the development of national innovation systems on the economic efficiency. In order to achieve the purpose, the following tasks are determined: 1) development of integrated indicators to evaluate operating efficiency of national innovation systems; 2) identification of interrelation between the level of development of national innovation systems and the level of economic development of countries; 3) evaluation of development of individual national innovation systems; 4) determination of influence of the level of national innovation systems' development on the economic growth of countries.

The methodology of research of influence of development level of national innovation systems on the economic growth of countries is based on building integral indices, which are calculated by using the method of geometric average of partial indices and construction of regression models, which allow evaluating the influence of development of national innovation systems on the economic efficiency.

\section{Issues of formation and evaluation of the operation of national innovation systems}

Given the wide range of updated or newly created processes, products, solutions, etc. predicted by innovations, there is a need to create a system that would ensure the introduction of innovations into economic activity.

Creation and development of modern national innovation systems are regulated at the legislative level. The legislative framework for the functioning of national innovation systems began to form in the 80 s of the XX century on the basis of regulation of technological innovations. At the beginning of the XXI century, such a legislative framework was formed almost in all countries of the world and continues to improve at the expense of regulation of state innovation policy, the activity of separate institutions, and formation of development concepts of national innovation systems.

In particular, in Ukraine in 2009, there was approved the Concept of Development of National Innovation System (Order of the Cabinet Ministers of Ukraine, 2009), which purpose is to create conditions for increasing labour efficiency and competitiveness of domestic producers by means of technological modernization of national economy, improving the level of their innovative activity, production of innovative products, application of advanced technologies, methods of organization and management of economic activity in order to improve human well-being and ensure sustainable economic growth.

The level of competitiveness of national economy depends exactly on the efficiency of functioning of the national innovation system. So, according to data from the World Economic Forum, it is the influence of innovative factors on economic development that is one of the most important parameters of the national economic competitiveness index. In 2017-2018, the economy of Ukraine was at the 81st place in the world by the level of competitiveness, which is determined, first of all, by innovative and educational factors. Thus, by the level of development of national innovation system, Ukraine occupies the 61st place (by the presence of researchers -25 th place, by the potential for innovation - 51st place, by the level of patenting - 52nd place, by the level of quality of research institutions 60 th place, by the level of higher education -35 th place, by the level of the primary education - 53rd place). Whereas according to core indicators - 96th place, the efficiency of commodity markets - 101st place, the efficiency of the labour market - 86th place, the development of the financial market - 120th place (The Global Competitiveness Report, 2017-2018).

As an additional confirmation of the previous conclusion, it should be noted that in 2017-2018, the highest level of competitiveness is in Switzerland (1st place), the USA (2nd place), Singapore (3rd place), the Netherlands (4th place), and Germany (5th place). As an example, the level of development of innovation system in Switzerland is also the highest in the world - 1st place, innovation system of the USA - 2nd place, while other groups of factors of competitiveness level of economies of these counties range from 1 to 83 (The Global Competitiveness Report, 2017-2018). The data of the Global Innovation Index can serve as a confirmation of foregoing data (The Global Innovation Index, 2017). By 2017, Switzerland ranked 1st in the world by the level of the Global Innovation Index, while the Netherlands (3rd place), the USA (4th place), Singapore (7th place), and Germany (9th place) also belong to the countries with the highest level of innovation activity. Therefore, 
based on using various methodologies and indicators, one can affirm that the influence of efficiency of national innovation system on the level of competitiveness of national economy is determinant and absolute.

Issues in determining the efficiency of innovative development of the economy are studied for a long time. Basic developments in this field are carried out at the beginning of the 90s of the XX century when the first methodological tools to evaluate innovations began to emerge (Oslo Manual (Oslo Manual, 1992), Using Patent Data as Science and Technology Indicators (Using Patent Data as Science and Technology Indicators - Patent Manual, 1994) and so on). However, research in the field of efficiency of national innovation system continues.

In general, two groups of methods are used for analysing the efficiency of national innovation systems: parametric (with exact characteristics of the resulting evaluations) and nonparametric (based on a stochastic evaluation of the resulting estimates). The main methods of evaluation of the efficiency of national innovation systems include data envelopment analysis (DEA), deterministic frontier approach (DFA), stochastic frontier approach (SFA) (Kotsemir, 2013).

Thus, evaluation of the efficiency of national innovation systems is carried out as on the basis of international comparison of performance indicators of different national innovation systems, so based on the development of analytical models or integral indicators (Balzat, Hanusch, 2004).

\section{Review of theory and literature}

Researchers conducted an evaluation of the efficiency of a number of national innovation systems. So, B. Jankowska, A. Matysek-Jędrych, and K. MroczekDąbrowska (2017) carried out an evaluation of the efficiency of national innovation systems of Poland and Bulgaria. G. Hua (2015) evaluated the efficiency of China's national innovation system. J. Guan i K. Chenc (2012) applied data envelopment analysis (DEA). Koria R. et al (2014, p. 1-18) conducted a comparative analysis of the efficiency of national innovation systems of Ghana and Kenya.

For today, the OECD (Organisation for Economic Cooperation and Development) system of indicators became the most widespread (OECD, 1997), based on which the evaluation of the relationship of innovation activity with economic efficiency and economic growth is carried out. However, problems of assessing the availability, quality, and completeness of the use of resources, their availability, and link between institutes of national innovation systems, the effectiveness of processes for creating innovation, the mechanism for their expansion are not resolved (Titarenko, 2013). Moreover, there is no generally accepted system of indicators that determine the scale, strength, and efficiency of operation of national innovation systems.

In order to evaluate the operating efficiency of national innovation systems, most of the researchers develop their own methods by improving existing nonparametric methods. As a rule, researchers develop integral indicators, based on which assessment of the operating efficiency of national innovation systems is carried out. Methods developed by B. Jankowska, A. Matysek-Jędrych i K. Mroczek-Dąbrowska (K-means clustering) can serve as examples of such developments (2017).

Formation of integral indicators for evaluating the operating efficiency of national innovation systems and their influence on the economy, as a rule, is taking place based on the consideration of separate spheres of national innovation systems. In particular, the work (Jankowska, Matysek-Jędrych, Mroczek-Dąbrowska, 2017) considers 7 spheres of national innovation systems (Institutions, Human capital and research, Infrastructure, Market sophistication, Business sophistication, Knowledge and technology outputs, Creative outputs), which are described by individual indices.

\section{Evaluation of national innovation systems' efficiency}

In order to concretize formation of an integral indicator of evaluation of national innovation systems' efficiency, it is appropriate to consider 4 directions of the functioning of subjects of national innovation systems, which is the basis for the formation of GDP of any national economy:

1) entrepreneurial activity;

2) innovative activity;

3) educational and professional activities;

4) welfare of the population.

We propose to evaluate the level of national innovation systems' efficiency based on a single integral indicator an index of development of national innovation systems.

We recommend calculating the development of national innovation system index $\left(I_{D N I S}\right)$ by the formula of geometric average of partial indices, which characterize all directions of the functioning of subjects of national innovation systems:

$$
I_{D N I S}=\sqrt[4]{I_{D E} * I_{D I A} * I_{D E P A} * I_{W P}} ;
$$

where $I_{D E}$ - entrepreneurship development index;

$I_{D I A}$ - innovation activity development index;

$I_{D E P A}$ - development of educational and professional activities index;

$I_{W P}$ - the welfare of the population index.

The calculation of the integral indicator on the basis of product of indices will provide the reasonableness and methodological correctness of comparisons of parameters of national innovation systems' operation on the basis of the universal scale and will allow performing correct comparisons both as by an integral index of the 
development of national innovation systems and in the context of its individual elements.

The proposed methodology for calculating the integral index of national innovation systems' development envisages building partial indices of separate directions of national innovation systems' operation. This allows avoiding excessive information load of the integral index, however, allows conducting a complex assessment of the level of national innovation systems' development, reducing the influence of infoglut, and carrying out strategic management of separate directions of national innovation systems' operation.

Therefore, elements of national innovation system development index are four main indices, which calculation considers all parameters of development of national innovation systems according to abovementioned four directions of the functioning of subjects of national innovation systems.

In particular, based on development entrepreneurship index $\left(I_{D E}\right)$, the level of entrepreneurial activity development in the country's economy is taken into account:

$$
I_{D E}=\sqrt[4]{I_{N E} * I_{C} * I_{T} * I_{E D B}}
$$

where $I_{N E}$ - enterprises number index;

$I_{C}$ - gross capital formation index;

$I_{T}$ - turnover or gross premiums written index;

$I_{E D B}$ - Ease of Doing Business index.

In such a way, the evaluation of entrepreneurship activity in the country in general is carried out at the expense of applying the entrepreneurship development index, which allows evaluating general business potential of economic entities in the country, conducting a comparison of such a potential of individual economies, and taking into account the activity of all potential subjects of national innovation systems.

From the point of view of the effectiveness of national innovation systems, the most important is the innovation activity development index $\left(I_{D I A}\right)$ :

$$
I_{D I A}=\sqrt[4]{I_{I P} * I_{R D E} * I_{R} * I_{P}} ;
$$

where $I_{I P}-$ charges for the use of intellectual property index;

$I_{R D E}$ - research and development expenditure index;

$I_{R}$ - researchers in R\&D index;

$I_{P}$ - patent applications, residents and non-residents index.

The use of such an index will allow evaluating general level of innovative activity in the country's economy, as well as considering the main parameters of innovation systems based on different approaches: on the basis of a revenue-based approach - because it considers revenues generated by the commercialization of innovations, based on the cost-oriented approach - since it takes into account the costs of financing innovations, as well as on the basis of the approach for assessing labour potential because it takes into account the number of researchers and the amount of patenting of innovations.
We recommend calculating the development of educational and professional activities index $\left(I_{D E P A}\right)$ as follows:

$$
I_{D E P A}=\sqrt[3]{I_{L F A E} * I_{U} * I_{E E}} ;
$$

where $I_{L F A E}$ - labour force with advanced education index;

$I_{U}$ - unemployment index;

$I_{E E}$ - adjusted savings: education expenditure index.

The use of such an index will allow evaluating the general level of educational attainment in the country as on the basis of labour potential indicators, so based on dynamics of education financing. Also, an important element of such an index is taking into account unemployment level that ensures considering the negative impact the exclusion of a part of employees from the innovation system.

We consider appropriate to calculate the welfare of the population index $\left(I_{W P}\right)$ as follows:

$$
I_{W P}=\sqrt[3]{I_{G D I} * I_{H E} * I_{I}}
$$

where $I_{G D I}$ - gross domestic income, derived as the sum of GDP and the terms of trade adjustment index;

$I_{H E}$ - household final consumption expenditure index;

$I_{I}$ - inflation index.

The application of such an index is absolutely necessary from the viewpoint of confirmation of the final goal of the functioning of national innovation systems - increasing the welfare level of the population

The methodology for calculating indices $I_{N E}, I_{C}, I_{T}, I_{I P}, I_{R D E}, I_{R}, I_{P}, I_{L F A E}, I_{E E}, I_{G D I}, I_{H E}$ is as follows:

$$
I=\frac{x_{1}}{x_{0}}
$$

where $x_{1}, x_{0}$ - current and previous values of indicators.

The methodology for calculating indices for $I_{E D B}, I_{U}, I_{I}$ is as follows:

$$
I=\frac{x_{0}}{x_{1}}
$$

where $x_{1}, x_{0}$ - current and previous values of indicators.

Testing of the methodology of evaluation of national innovation systems' development is carried out based on data of national innovation systems of six countries: Ukraine, Great Britain, Latvia, Germany, Poland, and France. Calculation of the national innovation system development index and its individual elements is made according to data for the last decade: for the period of 2006-2016.

For all abovementioned countries, indices of national innovation systems' development for 2006-2016 were calculated (Table 1). This allowed obtaining the initial data for the second task of scientific research - the establishment of the interrelation between the level of development of national innovation systems and the 
level of economic development of countries, as well as the influence of the development of innovation systems on economic efficiency.

\section{Influence of the level of national innovation systems' development on economic growth}

The level of development of national innovation systems was determined based on development indices of national innovation systems, while the level of economic development of the country was determined based on GDP per capita index.

In order to analyse the relationship of the index of development of national innovation systems, its elements, and GDP per capita index, there is built a matrix of correlations presented in Table 2.

According to data from Table 2, it can be concluded that there is a close positive interrelation between the index of national innovation systems' development and the index of GDP per capita, which is peculiar for all countries from the sample. This testifies that the growth of values of the index of national innovation systems' development is accompanied by an increase in the GDP per capita index, and consequently - an improvement of the indicators of innovation in the country leads to an increase in the efficiency of national economies. This conclusion is valid for all studied countries.

Based on analysing elements of the index of national innovation systems development, one can argue about the availability of a close positive interrelation of the development of educational and professional activities and improvement of the population welfare level and GDP per capita for all the analysed sample of countries, which is confirmed by values of corresponding correlation coefficients close to 1 .

Instead, there is no single trend in the formation of interconnections between the level of entrepreneurial activity, as well as innovation activity and GDP per capita. For example, in Great Britain, Latvia, and France, there is a close positive relationship between the level of entrepreneurship development and GDP per capita, which is confirmed by the proper economic situation in the countries. However, the crisis situation in Ukraine leads to a weak negative relationship between the level of entrepreneurship development and GDP per capita, as evidenced by the value of the correlation coefficient at -0.2864 , and therefore, we can conclude that the level of entrepreneurship activity in Ukraine is low, and also, there is a high level of economy's shadowing.

Values of correlation coefficients of the index of innovation development and the index of GDP per capita require additional explanation. Practically for all the analysed countries (except Ukraine), a weak positive relationship between the development of innovation activity and GDP per capita was identified, which, at first glance, is strange for highly developed countries whose economy is based on an innovative approach. However, the main explanation for the revealed interrelation is that the level of development of many national innovation systems (in particular, Great Britain, Latvia, Poland, and France) is extremely high and its further growth is slow and it causes significant fluctuations in the resulting figures. While Ukraine has a significant reserve of growth in the level of development of the national innovation system precisely due to the development of

Table 1

Results of the calculation of the national innovation systems development index

\begin{tabular}{|l|c|c|c|c|c|c|c|c|c|c|}
\hline \multicolumn{1}{|c}{ Country } & 2007 p. & 2008 p. & 2009 p. & 2010 p. & 2011 p. & 2012 p. & 2013 p. & 2014 p. & 2015 p. & 2016 p. \\
\hline Ukraine & 1,1065 & 1,0621 & 0,8832 & 1,0636 & 1,0526 & 1,0447 & 1,0511 & 0,8881 & 0,9079 & 1,0476 \\
\hline Great Britain & 1,0320 & 0,9848 & 0,9129 & 1,0134 & 1,0089 & 0,9864 & 1,0319 & 1,0917 & 1,0348 & 0,9905 \\
\hline Latvia & 1,0401 & 1,0405 & 0,7704 & 1,0197 & 1,1589 & 1,0285 & 1,0216 & 0,9526 & 0,9327 & 1,0918 \\
\hline Germany & 1,0547 & 1,0338 & 0,9756 & 1,0436 & 1,0544 & 1,0017 & 1,0286 & 1,0638 & 0,9881 & 1,0279 \\
\hline Poland & 1,0547 & 1,0961 & 0,9208 & 1,0681 & 1,0432 & 1,0183 & 0,9975 & 1,0674 & 1,0108 & 0,9954 \\
\hline France & 1,0623 & 1,0445 & 0,9419 & 1,0416 & 1,0256 & 0,9733 & 1,0182 & 1,0279 & 0,9749 & 1,0209 \\
\hline
\end{tabular}

Source: calculated by the authors according to data (State Statistics Service of Ukraine, Trading Economics, Eurostat, World Bank)

Table 2

The matrix of the correlation of the national innovation systems development index, its elements, and GDP per capita index

\begin{tabular}{|l|c|c|c|c|c|}
\hline \multirow{2}{*}{ Countries } & \multicolumn{5}{|c|}{ Indicators } \\
\cline { 2 - 6 } & $\mathrm{I}_{\mathrm{DE}}$ & $\mathrm{I}_{\mathrm{DIA}}$ & $\mathrm{I}_{\mathrm{DEPA}}$ & $\mathrm{I}_{\mathrm{WP}}$ & $\mathrm{I}_{\mathrm{DNIS}}$ \\
\hline Ukraine & $-0,2864$ & 0,7484 & 0,8886 & 0,9367 & 0,9552 \\
\hline Great Britain & 0,5961 & 0,3079 & 0,7607 & 0,9760 & 0,7821 \\
\hline Latvia & 0,7124 & 0,1177 & 0,8527 & 0,9523 & 0,6720 \\
\hline Germany & 0,1753 & 0,5818 & 0,8807 & 0,9893 & 0,8361 \\
\hline Poland & 0,4074 & 0,0592 & 0,7840 & 0,9990 & 0,8053 \\
\hline France & 0,6020 & 0,2145 & 0,8728 & 0,9930 & 0,8305 \\
\hline
\end{tabular}

Source: calculated by the authors according to data (State Statistics Service of Ukraine, Trading Economics, Eurostat, World Bank) 
innovative activities of economic entities. Therefore, the development of the national innovation system in general and innovation activity in particular are extremely important for Ukraine, since such measures will be accompanied by a significant increase in GDP per capita.

In order to reveal interdependences between the index of national innovation systems' development and the index of GDP per capita, regression models were built (Table 3). Building such linear regression models was carried out based on data from six countries (Ukraine, Great Britain, Latvia, Germany, Poland, France) for the period of 2006-2016.

Table 3

Regression models of the interrelation of the index of national innovation systems development and the index of GDP per capita

\begin{tabular}{|l|c|c|}
\hline \multicolumn{1}{|c|}{ Countries } & Model & $\mathrm{R}^{2}$ \\
\hline Ukraine & $\mathrm{Y}=-1,7826+2,7760^{*} \mathrm{I}_{\mathrm{DNIS}}$ & 0,9124 \\
\hline Great Britain & $\mathrm{Y}=-0,6121+1,5931^{*} \mathrm{I}_{\mathrm{DNIS}}$ & 0,6116 \\
\hline Latvia & $\mathrm{Y}=-0,2143+1,2613^{*} \mathrm{I}_{\mathrm{DNIS}}$ & 0,5515 \\
\hline Germany & $\mathrm{Y}=-1,6392+2,5871^{*} \mathrm{I}_{\mathrm{DNIS}}$ & 0,6991 \\
\hline Poland & $\mathrm{Y}=-1,2612+2,240{ }^{*} \mathrm{I}_{\mathrm{DNIS}}$ & 0,6485 \\
\hline France & $\mathrm{Y}=-0,9577+1,9367^{*} \mathrm{I}_{\mathrm{DNIS}}$ & 0,6897 \\
\hline
\end{tabular}

Source: calculated by the authors according to data (State Statistics Service of Ukraine, Trading Economics, Eurostat, World Bank)

All the models obtained have a high level of reliability $\left(\mathrm{R}^{2}>0,5\right)$, which testifies to the possibility of their practical application for the purpose of forecasting resulting indicator. Also, for all models, there is observed a direct linear interdependence between the index of national innovation systems development and the index of GDP per capita, which proves the necessity of further intensive development of national innovation systems in order to ensure effective development of the economy in general.

In order to detail the interdependence between elements of the index of national innovation systems development and the index of GDP per capita on the basis of analogous statistical data, linear regression models of the interrelation of elements of the index of national innovation systems development and the index of GDP per capita are built (Table 4).
The reliability of obtained regression models is considerably higher $\left(\mathrm{R}^{2}>0,9\right)$ that provides the possibility to use them for the purpose of forecasting GDP per capita in terms of national innovation systems' development. It should be noted that the influence of separate elements of the index of national innovation systems development differs for different countries (Table 5).

\section{Table 5}

The nature of the influence of elements of the index of national innovation systems development on the index of GDP per capita (direct/inverse)

\begin{tabular}{|l|c|c|c|c|}
\hline \multicolumn{1}{|c|}{ Countries } & $\mathrm{I}_{\mathrm{DE}}$ & $\mathrm{I}_{\mathrm{DIA}}$ & $\mathrm{I}_{\mathrm{DEPA}}$ & $\mathrm{I}_{\mathrm{WP}}$ \\
\hline Ukraine & direct & direct & direct & direct \\
\hline Great Britain & direct & inverse & inverse & direct \\
\hline Latvia & direct & inverse & inverse & direct \\
\hline Germany & direct & inverse & inverse & direct \\
\hline Poland & inverse & direct & direct & direct \\
\hline France & direct & direct & direct & direct \\
\hline
\end{tabular}

Source: calculated by the authors according to data (State Statistics Service of Ukraine, Trading Economics, Eurostat, World Bank)

For Ukraine, as well as for France, a direct linear dependence of economic development on the dynamics of all elements of the index of national innovation systems development (entrepreneurial, innovation, educational and professional activities, and welfare of the population) is observed. Therefore, in order to achieve sustainable economic growth in these countries, it is necessary to ensure the development of national innovation systems by all four abovementioned elements. At the same time, a priority of economic growth in Great Britain, Latvia, and Germany is the development of entrepreneurial activity and increase in the welfare of the population. While innovation activity and educational and professional activities in these countries are maximally developed and thus may remain at the current level of development or grow at a low pace, since additional investment in these activities will not have a significant impact on GDP growth in the countries. Instead, in Poland, a high level of small business development is revealed (which constitutes about $95 \%$ of economic entities), which does not allow directly influencing the growth of the economic

Table 4

Regression models of the interrelation of elements of the index of national innovation systems development and the index of GDP per capita

\begin{tabular}{|c|c|c|}
\hline Countries & Model & $\mathrm{R}^{\wedge} 2$ \\
\hline Ukraine & $\mathrm{Y}=-2,824+1,564^{*} \mathrm{I}_{\mathrm{DE}}+0,377^{*} \mathrm{I}_{\mathrm{DIA}}+0,218^{*} \mathrm{I}_{\mathrm{DEPA}}+1,580^{*} \mathrm{I}_{\mathrm{WP}}$ & 0,967 \\
\hline Great Britain & $\mathrm{Y}=-1,744+0,104{ }^{*} \mathrm{I}_{\mathrm{DE}}-0,149{ }^{*} \mathrm{I}_{\mathrm{DIA}}-0,462^{*} \mathrm{I}_{\mathrm{DEPA}}+3,230^{*} \mathrm{I}_{\mathrm{WP}}$ & 0,977 \\
\hline Latvia & $\mathrm{Y}=-2,286+0,175^{*} \mathrm{I}_{\mathrm{DE}}-0,0344^{*} \mathrm{I}_{\mathrm{DIA}}-0,337^{*} \mathrm{I}_{\mathrm{DEPA}}+3,484^{*} \mathrm{I}_{\mathrm{WP}}$ & 0,912 \\
\hline Germany & $\mathrm{Y}=-2,479+0,055^{*} \mathrm{I}_{\mathrm{DE}}-0,296{ }^{*} \mathrm{I}_{\mathrm{DIA}}-0,206{ }^{*} \mathrm{I}_{\mathrm{DEPA}}+3,928{ }^{*} \mathrm{I}_{\mathrm{WP}}$ & 0,985 \\
\hline Poland & $\mathrm{Y}=-2,025-0,064{ }^{*} \mathrm{I}_{\mathrm{DE}}+0,096 \mathrm{I}_{\mathrm{DIA}}+0,114^{*} \mathrm{I}_{\mathrm{DEPA}}+2,852{ }^{*} \mathrm{I}_{\mathrm{WP}}$ & 0,999 \\
\hline France & $\mathrm{Y}=-1,970+0,030^{*} \mathrm{I}_{\mathrm{DE}}+0,048^{*} \mathrm{I}_{\mathrm{DIA}}+0,053^{*} \mathrm{I}_{\mathrm{DEPA}}+2,825^{*} \mathrm{I}_{\mathrm{WP}}$ & 0,988 \\
\hline
\end{tabular}

Source: calculated by the authors according to data (State Statistics Service of Ukraine, Trading Economics, Eurostat, World Bank) 
efficiency. Therefore, in order to ensure the growth of GDP, first of all, Poland should promote the growth of innovation and also educational and professional activities and welfare of the population.

\section{Conclusions}

Development of modern global economic system is taking place on the basis of the concept of "knowledge economy". And thus the main method to stimulate economic development is to introduce innovations. Formation of national innovation systems allowed, on the one hand, providing formation of synergetic effect from the cooperation of many participants of innovative process and, on the other, making the state a key subject of the development of national economy by means of formation of state innovation policy. Thus, states receive another one tool to improve the level of competitiveness of national economies under conditions of global competition at the expense of national innovation systems development.

The main group of methods for analysing the efficiency of national innovation systems is nonparametric methods, and applications of own approaches for improving existing nonparametric methods at the expense of development of integral indicators for evaluating the operating efficiency of national innovation systems have become widespread among scholars. In the paper, the author's method of forming integral indicator to evaluate the level of development of national innovation systems is developed and the method to evaluate their influence on the economy is proposed.

It is proposed to concretize formation of national innovation systems on the basis of 4 directions of functioning of subjects of national innovation systems (entrepreneurial activity, innovative activity, educational and professional activities, welfare of the population), which consideration is taking place during the calculation of integral indicator that reflects the level of development of national innovation systems - the national innovation systems development index.

Testing of the methodology of evaluation of national innovation systems' development is carried out based on data of national innovation systems of six countries: Ukraine, Great Britain, Latvia, Germany, Poland, and France. For all abovementioned countries, indices of national innovation systems development were calculated according to data for 2006-2016. This allowed obtaining the initial data for the second task of scientific research - the establishment of the interrelation between the level of development of national innovation systems and the level of economic development of countries. And, therefore, the paper proves the necessity of further intensive development of national innovation systems in order to ensure effective development of the economy in general.

The work proves the existence of a close positive interrelation between the index of national innovation systems' development and the index of GDP per capita, which is peculiar for all countries from the sample. This testifies that the growth of values of the index of national innovation systems' development is accompanied by an increase in the GDP per capita index, and consequently - an improvement of the indicators of innovation activity in the country leads to an increase in the efficiency of national economies and their competitiveness level.

Construction of regression models according to data of calculation of the index of national innovation systems' development and its elements with a quite high reliability will allow using them in order to forecast GDP per capita under conditions of national innovation systems' development.

Also, the paper identifies features of the influence of separate directions of the functioning of innovation systems on the level of economic development of the countries under study. In particular, it is proved that high level of innovation development almost in all countries under study (except Ukraine) does not allow to achieve significant economic growth precisely because of the active stimulation of innovation activity. And thus it is appropriate to stimulate the development of national innovation systems of abovementioned countries through other directions (in particular, entrepreneurship activity, educational and professional activities). However, it is worthwhile to stimulate the development of national innovation system of Ukraine, above all, at the expense of intensification of innovation activity, which will make a considerable positive impact on the country's economic growth.

So, the paper proposes the author's method for evaluating the development of national innovation systems on the basis of calculation of integral indicator that reflects the level of development of national innovation systems - the index of national innovation systems development. Testing of the methodology of evaluation of national innovation systems' development is carried out based on data of national innovation systems of six countries: Ukraine, Great Britain, Latvia, Germany, Poland, and France; the existence of a close positive interrelation between the index of national innovation systems' development and the economic growth in analysed countries is proved. The possibility of practical application of the proposed method for evaluating the development level of national innovation systems increases the importance of the results obtained. 


\section{References:}

Balzat, M., \& Hanusch, H. (2004) Recent trends in the research on national innovation systems. Journal of Evolutionary Economics, Vol. 14, Iss. 2, 197-210.

Fagerberg, J., Mowery, D., \& Nelson, R. (Eds.). (2005) Oxford Handbook of Innovations. Oxford University Press. Fedirko, O. (2007) National innovation system as an object of state innovation policy. International economic policy, 1(6): 63-88.

Guan, J., \& Chenc, K. (2012) Modeling the relative efficiency of national innovation systems. Research Policy, 41: $102-115$.

Hua, G. (2015) Research on China's Regional Innovation Efficiency and Influence Factors Based on SFA. International Journal of Management Science, Vol. 2, No. 2. Electronic resource. Retrieved from: http://www.aascit.org/journal/archive?journalId=917\&issueId=9170202

Jankowska, B., Matysek-Jędrych, A., \& Mroczek-Dąbrowska, K. (2017) Efficiency of National Innovation Systems - Poland and Bulgaria in the Context of the Global Innovation Index. Comparative Economic Research, Vol. 20, Num. 3: 77-94.

Koria, R., Bartels, F., Andriano, L., \& Koeszegi S. (2014) Effectiveness and Efficiency of National Systems of Innovation: the importance of ICT, the Cases of Ghana and Kenya. IST-Africa 2014 Conference. Electronic resource. Retrieved from: http://www.ist-africa.org/Conference2014/

Kotsemir, M. (2013) Measuring national innovation systems efficiency - a review of dea approach. Electronic resource. Retrieved from: https:9/papers.ssrn.com/sol3/papers.cfm?abstract_id=2304735

Nelson, R.R. (2000). National Innovation Systems. In: Acs, Z.J. (Ed.), Regional Innovation, Knowledge and Global Change. London: Pinter.

OECD. National Innovation Systems. (1997) Electronic resource. Retrieved from: https://www.oecd.org/science/ inno/2101733.pdf

Official site of the State Statistics Service of Ukraine. Electronic resource. Retrieved from: http://www.ukrstat.gov.ua Order of the Cabinet Ministers of Ukraine "On Approval of the Concept of Development of the National Innovation System" dated June 17, 2009, № 680-p. Electronic resource. Retrieved from: http://zakon3.rada.gov.ua/laws/ show/680-2009-\%D1\%80

Sharif, N. (2006) Emergence and development of the National Innovation Systems concept. Research Policy, 35: 745-766.

The Global Competitiveness Report 2017-2018. Electronic resource. Retrieved from: http://www3.weforum.org/ docs/GCR2017-2018/05FullReport/TheGlobalCompetitivenessReport2017\%E2\%80\%932018.pdf

The Global Innovation Index 2017. Electronic resource. Retrieved from: https://www.globalinnovationindex.org/ home

Titarenko, H. B. (2013) Trends in the development of the national innovation system in Ukraine. Visnyk SumSU, Series Economics, 4: 155-161.

Trading Economics. Electronic resource. Retrieved from: https://tradingeconomics.com

Website of Eurostat. Electronic resource. Retrieved from: http://ec.europa.eu/eurostat/data/database Website of the World Bank. World Bank Group. Electronic resource. Retrieved from: https://data.worldbank.org/ indicator 